\title{
Debunking the Legacy of "Kaburu" Biblical Hermeneutics in Kenya Through a Postcolonial Reading of Socioeconomic Parables in Luke's Gospel
}

\author{
Musa Maina ${ }^{1}$ \\ Faculty of Theology, St. Paul's University, P. O. Private Bag - Limuru, Kenya \\ Julius Kithinji ${ }^{2}$ \\ Faculty of Theology, St. Paul's University, P. O. Private Bag - Limuru, Kenya
}

\begin{abstract}
Biblical interpretations in post-colonial Kenya and probable in other geopolitical spaces remain indebted to early western missionaries' lensed biblical "optics," still very steeply influential in the way the Bible is read and interpreted. Whereas their contributions to the presence and the growth of the church cannot be underestimated, the legacy and validity of their hermeneutics in post-colonial contexts (Kenya) remain questionable and wanting. This is so because of its failure to adequately address the dire existential and contextual concerns of communities of faith in their commitment to serve prophetically. Fostered during colonial era, the hermeneutics give peripheral attention to glaring social economic and political distresses affecting the majority of people while a few, mostly rich and powerful live in unmerited affluence. For recourse, this paper deems postcolonial frameworks of interpretation as appropriate for reading scriptures anew. To demonstrate its efficacy, it enjoins two socioeconomic parables from Luke's gospel (12:16-21, 15:11-32) for exegetical review and whose goal is to demonstrate that biblical readings must of essence be proactively context sensitive, liberating and transforming. By calling for a debunking of the missionary hermeneutics in favour of postcolonial readings, this paper advocates for reception of the gospel not as a message of personal salvation from the world, but as the message of a world transfigured right down to its basic structure, the household (Oikos).
\end{abstract}

Keywords: Bible, Postcolonial, "Kaburu Legacy," Eurocentric, hermeneutics, Missionary

DOI: $10.7176 / \mathrm{JPCR} / 53-01$

Publication date: April $30^{\text {th }} 2021$

\subsection{Introduction}

Most post-colonial formerly mission founded churches in Kenya face daunting challenges when it comes to their mission engagements mostly because of the deep influence of hermeneutics fostered by early missionaries. During the missionary enterprise in colonial Kenya, the disquiet dispositions of the missionaries preaching in the midst of socioeconomic and political evils occasioned by colonialism, remains a grave matter of interest, thus "It was not unusual for missionaries such as John Mackenzie to call for the colonization of the native people" (Dube 2012: 22). The fact that same exploitations took place and thrived and even in today's Kenya postcolonial context makes that legacy and hermeneutics suspect and in need of debunking, and a more progressive and proactive context sensitive lens(s) embraced. The inadequacy of that legacy is notable in that "initial colonial churches anticipated a relationship of dependence or one that was informed by colonial racism, where African believers were not expected to do their own thinking or to provide independent leadership" (Sugirtharajah 2016:9).

Postcolonial theory is hereby deemed appropriate in view Donaldson $(2002: 100)$ who shows that the "optics" are both sensitive to the environment(s) that "birthed" and shaped biblical narratives, and to the (con)texts of the reader(s). (Con)texts is hereby taken seriously, whether it is that of the text itself or of the reader (interpreter) because either way, both are the social space(s) where power of (dis)empowerment is executed and either affirmed or contested.

For the colonial and missionary era, the missionaries' choice and biblical readings is suspect raising the

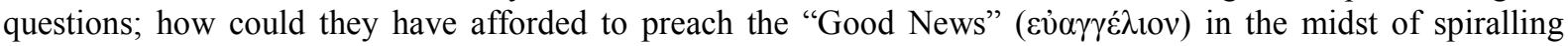
colonial violence without condemnation? How did they read the read the Bible to harmonize it with evils of the colonization project? These questions are central to this paper, and hence the call to abandon the "alien" missionary inculcated hermeneutics and in its place embrace postcolonial "optics" also lauded as "a conscious decolonizing and suspicious reading" (Dube 2012:24).

\subsection{Alien Biblical Interpretations}

The introduction of Christianity and Bible in Africa meant readings of the Bible and interpretations by the missionaries during a traumatizing era of colonialism and as such remained unresolvedly baffling and wanting. Their silence and the gospel they preached when human life was under serious threat made them suspect, 
culpable and guilty. This is so because the overarching thrust of the Gospel's message is in its nature redemptive (Luke 4:18ff), putting human dignity and equity at the centre of all preaching. Failure to take cognizance of this like the missionaries did has puzzled Kenyan biblical postcolonial theorists making them to cast doubt not only on the role of the missionaries, but more fundamentally on the role of the Bible in aiding colonialism. Kithinji for example, argues that "Luke's parables in Kenya context can be viewed as having two roles to play,... along with other biblical texts, Luke's parables have played the role of Christianizing the Kenyan society....along with other imperializing texts, Luke's parables have not only "authorized" the subjugation of foreign lands and nations..., but have also provided the imagery for the acceptance of the situation" (Kithinji, 2008: 81). Musa Dube, has also voiced reservation on the Bible's use: "The use of the Bible will always be linked to and remembered for its role in facilitating European imperialism...postcolonial hermeneutics is deeply suspicious of the Bible's own imperial charter" (Dube 2000:10). Others have blamed western scholars: "Generation of western scholarship have maintained that the thematic structure and content of New Testament materials discourage social and political interpretation... The emphasis has been primarily on religious salvation, not on social equity" (Blount 1995:5). It is from the above perspectives and the concern of failure of "Kaburu" (hereafter western missionary) biblical hermeneutics to overcome challenges then, and even today in postcolonial Kenya context that this paper calls for hermeneutical accountability.

\subsection{Biblical Interpretations: Missionaries and Judeo Christian and Patristic Traditions}

On the influence of Judeo Christian and patristic traditions on missionaries' readings and interpretation of scriptures, the negative impact caused is conspicuous. Their silence and non-committal on the evil of colonialism, coupled with their treatment of biblical texts as abstract devoid of existential concerns remains superfluous and suspect. The gospel as Wink underscores is "a context-specific remedy for the evils of Domination system (Wink, 1992:48). Fostering biblical interpretations that is context insensitive and influenced heavily by neo-platonic philosophy that understands the world as a competition between the earthly and the heavenly, the created order and all matter precipitously evil and imperfect, human body as evil, predisposed to lust, an exile place of punishment for the fallen soul, and whose only recourse is through "salvation" and renunciation of "sin" was and still is superfluous. Such for sure is a recipe and "silver" lining for exploitation, then and even today. For such interpretations, God is absently up in the sky, sustained by conquests and domination, and favours those who conquer. To this "God" the disempowered masses exist to perpetuate the power and privilege which gods have conferred the "king," the aristocracy, the colony and the priest (missionary) through pursuance of "obedience," "humility", "sacrifice", "meekness" among other biblical virtues, thus "normalising" their stifled aspirations. For this reason, Donaldson opines that the missionary enterprise was a "conversion space" whereby the colonized "emerged fully cloaked in colonial garment and devoted to the structures and policies of their former colonizers" (2002:101). Such initiation no doubt accorded colonialism a thriving environment where any challenge or protest against exploitation is taken with offense as "sinful" not only against those in power but also to God self: "People were created for the cultivation and service to gods, to build them temples, offer them sacrifice and obey their dictates" (Riley 1997:22).

\subsection{Biblical Interpretations: Leverage of Postcolonial Optics}

Among recent approaches that have emerged, mostly from marginal geopolitical spaces, and have shaped the landscape of biblical interpretations is postcolonial theoretical frameworks. These voices based on their experience and marginalization, agitate for a hearing in the midst of domineering voices that have for a long-time shaped conversation in the landscape of biblical interpretation. In postcolonial criticism, the point of departure is whether biblical interpretations and all interpretations work for redemption or for oppression and marginalization. Thus, scriptures are viewed as context sensitive and hence must take cognizance of the total wellbeing of persons both spiritually and existentially. Unlike the missionaries' treatments of the Bible as neutral and apolitical, postcolonial criticism underscores that no text is neutral, not even Jesus and the biblical God! All readings are subjective and therefore must be seen and heard as such. There is also the conviction that within biblical texts and all contexts, are competing charged loud and submerged voices and hence the need to note that "biblical interpretation in sub-Saharan Africa cannot be separated from politics, economics and cultural identity of the past and present" (Sugirtharajah 2016:9).

The preaching of only powerful salvific messages as propagated by missionaries must be treated as halftruth which run contrary to the many Jesus' advocacy on equity and social justice (Mathew 25:1ff, Luke 4:16-21, Acts 6:1-7). After all, biblical passages that are primarily salvific cannot be fully comprehended unless their social dimensions are accounted for as contributing into textual meaning processes. Texts in this respect do not have universal, closed, static and immobile meanings. They have multiple of meanings generated by active readers and as informed by their social locations and experience. The implication then is that Biblical texts embody possibilities of multiple interpretations whose concern is "the internal dynamics of power present within the text and its ancient historical context, as well as its external effects on contemporary church and culture" 
(Krause 2004:9). In this shift of understanding, the goal for postcolonial reading is a decolonization of that which has for a long time been masked as absolute and normative. It about the unmasking of the mask of colonial propaganda and the subversion of any domineering ideology by "re-membering," restoring and dignifying the undignified, the shamed and the dishonoured. Postcolonial "optics" is about shining the spotlight beyond the traditional models of interpretation to include the "ideologized" imperial wider environments that frames many (con)texts and as Gerald West articulates, "This includes reading against the geography of biblical and western imperialist, reading against racializing potential of biblical text (expressed in ethic terms) and the racial politics of western ideology..." (West, 2008:7). Such according to Jeremy Punt "allows the rethinking of biblical interpretation as among others increasingly characterized not only by the effects of colonialism but also by influences such as globalization..." (Punt, 2015:1).

From the above perspectives, it is apparent no text or the Bible for that matter can be read in a vacuum insofar as it affects the believers in their own context as the word of God by which they live. This happens whether the reader (interpreter) is aware or not. The context from where it is read and interpreted is then a choice that also is consequential. It is a choice because readers read from particular social space(s), be that a space of power or disempowerment. Space according to Musa Dube is critical "whether one refers to a geographical terrain, a physical abode, a body, or an imagined place or community, it is a site for interrogation of geometrics of power, of how these relations of power are secured and also of how they maybe unmasked" (Dube, 2012:22). Interpretation hence is consequential given the overbearing powerful effects on the people and their lives. Postcolonial readings therefore must be framed in relation to the societal institutions and in this case, the Kenya context. For many biblical texts, the reality of the presence of the Roman Empire and its influence as the context and the environment where the texts were premeditated, meditated, imagined, written and interpreted becomes critical for postcolonial interpretations. They have to be read and interpreted as essentially anti-imperialism by creating space(s) for conversation between the texts and the reader(s) to the extent that biblical voices that have for so long been marginalized, muted and trampled upon are heard - away with readings that sustain imperial and hegemonic interests.

\subsection{Postcolonial Biblical Interpretations: Luke and the Greco Roman World of Parables}

Among ways through which the gospel writers responded to the reality of the presence of the Roman Empire in all its manifestation included a re-representation of Jesus' teachings through parables. That the Roman Empire had become a very influential force in need of such responses is not controversial as Wink puts it: "The Roman empire had made itself the highest value and the ultimate concern, arrogating itself the place of God" (Wink, 1992: 300). Among leading NT scholar's renown for making significant contributions on matters Jesus' teachings through parables vis-à-vis the Greco Roman world include Crossan Dominic (1995:48), Herzog William (1994:1-4), Scott Brandon (1989, 205-215), and Riley Gregory (1997:97-138). Though their works have elicited varying reactions, they all find convergence on the idea that Jesus' teachings mostly were directed at the presence and reality of the exploitative and oppressive Roman Empire as a colonial regime. The impact of Jesus' teachings through parables is well documented as to be re-membered, hence "so unforgotten that the reader or hearer is forced inevitably to respond in words and deeds (Schottroff, 2006:103), or that "its primary purpose is to set up a challenging view of the practicalities of God's reign" (Longenecker, 2008:158). For Robert Funk, "Jesus mixed humour with subversive and troubling knowledge born of direct insight" (Funk, 1986:158), while Herzog perceives Jesus' parables in direct relationship with the Roman empire: "Parables were not earthly stories with heavenly meanings but earthly stories with heavy meanings, weighted down by an awareness of the workings of exploitation in the world of hearers" (Herzog, 1994:3). Crossan's view is that when a people is exploited by colonial exploitation, one obvious response is armed revolt, or military rebellion. But sometimes that situation of oppression is experienced as so fundamentally evil and so humanly hopeless that only transcendental intervention is deemed of use. God, and God alone must act to restore a ruined world to justice and holiness. This demands a vision and a program that is radical, countercultural, utopian, world negating, or, as scholars say, eschatological (Crossan, 1995:46).

Riley's perspective is such that Jesus' "life story was understood against the background of the stories of the Greek heroes of the wider Greco Roman world...He was a miracle worker, a teacher of divine wisdom much like a philosopher, and an innocent victim of the violence of the rulers, insofar as who opposed the religious and political power structures of his day could be called innocent" (Riley 1997: 1). It is out of these diverging reactions that for many of Jesus' hearers, Jesus carried many faces ranging from being a teacher, a story teller, a treasonable criminal and an imposter, a Jewish eschatological prophet or a social revolutionary. Parables as taught by Jesus and re-enacted by the gospel writers then, projected not so much the world of abstractions but a world as it concretely affected them daily, the world as represented by the Roman empire and which poor overtaxed people sought relief from paying taxes Is it lawful for us to give tribute to Caesar, or not? (Luke 20:22). Jesus' teachings also directly went against the groundings of Torah's teachings, thus "he is perceived as a breaker of Sabbath and other traditions. He associates not with rulers and the upper classes, but with prostitutes, 
tax collectors and society's rejects" (Riley, 1997: 88). Through parables therefore, Luke's Jesus responded to the prevailing injustices courtesy of the Roman Empire by unmasking, resisting and subverting imperial propaganda while at the same time calling his hearers to embrace an alternative living under God's reign.

\subsection{Unmasking Imperial Dimensions in the Parable of the Rich Man: (Luke, 12:16-21)}

The parable of the rich fool as it is called unveils concerns of economic security as is explicated by the rich man's counsel of himself to "eat," "drink "and merry (verse 19). This sense of security becomes misplaced and the rich man is cast as a fool before God, the very wealth cannot guarantee the very same life. Underlying the man's predicament is an imperialized economy anchored on systemic oppression that breeds very rich and powerful few and the oppressed. The rich man's fate hangs on colonial economic pendulum that treats wealth as a means for inward self-preservation. His actions to raze down his inadequate barns and replace them with larger ones to hoard surpluses for the year ahead is a reflection of agrarian life in rural colonial Palestine. Due to colonial presence, poverty becomes not a matter of choice or spiritual but concrete material of helplessness, destituteness, being colonized, humiliated, shamed and dishonoured among other despicable descriptions of the downtrodden. For the rich man, it is his control of land and the people that grants him "success" through exploitation. His wealth has nothing to do with merit or hard work but holding extensive tracts of land from the poor, a common feature in colonial Palestine. The man's piling of abundant harvest demonstrates a very exclusive self-aggrandizing appetite for wealth.

The opening statement in the parable, that is "the land of the rich man brought plentiful" (Verse 16). It presents the land as the subject of the story but that very quickly takes a spiral turn and the rich man addresses himself as the subject (my soul). He then controls and contemptuously directs the story, thus "throughout the story the man excludes others from it, never even attempting to introduce them" (Scott, 1989:135). In his selfestimation, the unmerited produce will sustain his life ahead, a thinking very oblivion to the plight of the masses he has exploited from. The man further usurps the role from the narrator thus "I will say..." (12:19) instead of the narrator's "and he said." In the same vein he has usurped the story from the narrator, he also usurps the harvest (surplus) from his poor victims whom he has taken advantage of. The "what shall I do for I have nowhere to store my crops" (Verse 17) is a disguised well veiled lucrative plan in a world of abject scarcity. His blinded colonial plan cannot be separated from the marginalized "others" (14:21), worsened by his desire to have more and all for his "Soul!" His food empire is unmasked when God declares its demise. From God's declaration, his material hoardings definitely will not be his and thus the "rich fool" truly becomes a fool! The question "whose will they be" unmasks the reality that the man is not truly rich but what he claims to have is corruption, plundered at the expense of poor colonial subjects. The power he displays hangs on imperial infrastructure. God calls him foolish signifying someone lacking foresight and sound judgment since from the biblical tradition, everything belongs to God (Ps 62:11ff, 2Cor 4:7). Luke's Jesus rejects the colonial ideology that legitimates unmerited wealth and poverty. No amount of accrued wealth keeps death at bay for the years ahead as misconstrued by the "rich" poor man. He has to face the ultimate and immediate opposite of God's "this very night" (Verse 20). He has to forfeit his life contrary to "hoarding" it for the "many years" (Verse 19).

\subsection{Overturning Imperial Tradition in the Parable of the Prodigal Son (Luke 15:11-32)}

The manifestation of Roman empire's ideological representations not only played out in banquets and in big cities where the disparity between the rich and the impoverished was conspicuous, but also in households (Oikos); deemed powerful citadels for colonial socialization. The parable of the "Prodigal Son" (15:11-32) displays such a fortress which according to Luke's casting becomes a space for contestations where conventional values and norms like roles, class, checks and balances all honed in Greco-Roman world are subversively overturned and decolonized. Instead of the oikos being the powerful place of (mis)administrating resources and thus (dis)empowerment, the father's role normally endowed with inalienable rights of control over and against the rest of the membership is assaulted. With deeply enmeshed colonial socialization and dominating imperial inculcation, rarely would the system allow a colonial subject or a family member other than the father to imagine other than being submissively normalized. In perspective of the parable under review, it is not farfetched to imagine and understand the condemnation of the young son after he prematurely asked for his share of inheritance; daring to transgress out of the imperialized oikos norms and worse squander everything with harlots. From the perspective of the Greco-Roman world, he stands condemned while the elder brother is sympathized as a "faithful" child of a "merciful" father. Having been branded prodigal and profiled so, the young son becomes not only prodigal but also a representation of shame and waywardness and whose restoration is only possible through punishment. He represents all sinners and tax collectors and the "unchurched" colonial subjects in need of "evangelization" and "salvation" through the forgiveness of sin, apart from which they stand condemned and consigned to a place of weeping and gnashing of teeth (Luke 13:28). In the parable, the agitated elder son is a representation of the Pharisees and scribes who oblivious of their sins, consider themselves obedient and thus merit automatic recognition and reciprocated reward from their father. 
From a postcolonial perspective, this parable unveils a scene in need of deconstruction and a re-construction. The new Oikos becomes a contested space where resistance against domination, exploitation and exclusion is wedged for the wellbeing of all. The ethos of the reconstructed Oikos must be devoid of othering. It becomes a representation of God's reign, a new "empire" represented by Luke's Jesus' actions of freely dining with "sinners" and "tax collectors" (7:34). The vehement disapproval by the Pharisees, epitomizes the elder son's misdemeanour where he refutes the return of his young sibling. Luke's Jesus indicts the Pharisees terming them hypocrites (12:1) who neglect justice and love (11:42) and are guilty of self-justification (16:14-15). In the parable Luke's Jesus indicts those that sustain imperialism and exposes the challenges enshrined in Roman Empire's imperial socioeconomic and political socialization which justifies exclusive social boundaries of either being "inside" or being "outside." This marked social boundary is the cause of fury by the elder son upon his father's welcome stance allowing the re-entry of the young son after "straying" into the outer "free" space outside the exclusive Oikos. The father's response that Son, you are always with me... runs contrary to Greco roman worldview where father as a patriarch representation is uncontested. The elder son finds the fathers demeanour unacceptable based on his "patriarchalized" and colonially lensed socialization where he sees his "rightful" entitlement being assaulted, thus his response in (15:29). He displays what defines his relationship with the father; not filial but that of "master/servant." His claim is premised on the many years of "obedient service" and on the father occupying a position of authoritative power within the exclusive Oikos, a favour he expects also based on having "never" disobeyed his command (Verse 29). For his imperially "ideologized" mindset, his father, like all fathers wields power to the creation and authorization of scarcity, and (mis)commands economic goods and so determines the fates of those in the household. This mental colonization is a replica of Roman empires configured economy where the emperor is revered as the "father" of the empire through whom all imperial benefactions are derived, " an imperial "theology' which proclaims the emperor as not only divine but also as the prince of peace"( Sugirtharajah 2016:9).

The father is a statesman of the Oikos conferred the powers to exert and (mis)administer economic proceeds as instruments of power. With such, the elder son is completely trapped, demobilized, blinded and cannot dare like his young sibling to go or even peep outside the colonial markings of the Oikos to "make merry with his friends" (Verse 29). His incapacitation is such that he cannot yearn for anything more than the naming of a

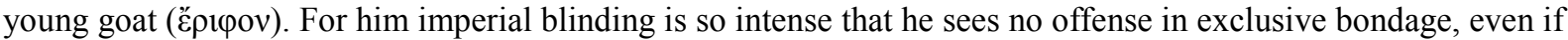
the conditions are harshly denting. His imperial lenses are opaque and can only afford him to "see" not only the clearly marked high social boundaries incapable of being crossed but also is conscious of the watchful eye of the powerful father. His posture as a colonial subject, is that of experiencing a mirage of security and stability that shield exploitative vices of colonialism.

The father's actions as earlier indicated is unconventional! He does not reprimand the "prodigal" son for his mis/behaviour nor take offense at his elder son's contemptuous remark "this son of yours" (Verse 30) nor his displeasure to killing a "fattened bull" ( $\sigma \tau \varepsilon v \tau o ̀ v ~ \mu o ́ \sigma \chi o v)$ for his party. For the young son, his daring to wander out of the shielded Oikos notwithstanding, he is not immune to imperial socialization. He perceives himself as an "outsider" (Verse 19) who must be denied re-entry into the Oikos where "insiders" are trapped looking upon themselves and detestably suspicious of "outsiders." Against Greco-Roman expectations, the father does not exercise paternal severity (colonial) towards him despite his self-acclaimed desire to be a "labourer" ( $\mu 1 \sigma \theta i \omega v)$. The father's contravention of every rule governing the administration of a colonial household, is further aggravated by him spearheading for a party, a sign of wealth and honour. He welcomes him happily even without the son's direct expression of apology (Verse 19, 21) a (mis)demeanour. According to Placher, "it is an amazing image; the father who doesn't even wait for the confession, who gives up all his dignity to run to the errant boy..., it undercuts many of our assumptions about the "father" as the symbol of stern judgment. The father symbolizes loving to the point of irresponsibility" (Placher, 2001:78). However, his action stands for deconstruction of colonial social boundaries of othering. Unlike his trapped elder son, the father welcomes the young son by border-crossing Oikos boundaries to engage his elder son. He wanders in and outside the colonial framings therefore bringing down the social walls that frame an "insider" and an "outsider." He demystifies markings and boundaries of colonial social spaces and reframes the Oikos as a space where new possibilities are re-imagined, re-created and re-envisioned. In this way, Luke rejects scarcity normalization and confronts the debilitating socioeconomic and political configurations of the Roman Empire. For Luke, a member of the Jesus movement, a new Oikos is visible, an Oikos that fosters inclusivity and is devoid of exploitation or obligated reciprocity. He unveils an occasion which would have turned threatening into a call for communion, where both the "prodigal" and the "obedient" have to commune without distinction made between the "prodigal" and the "obedient," the "insider" and the "outsider." Luke's Jesus hereby also overturns the Jewish pride of mosaic decree for absolute obedience to parents (Exodus 20:12). To the colonized mindsets, he pronounces his mission of "chaos" thus Do you think that I have come to bring peace to the earth? No! I tell you, but division... (Luke 12:51-53). Against all religious obligations, Luke's Jesus tells a man to leave his dying father, actually to ignore the filial obligation to see his burial for the sake of joining his movement (Luke 9: 59-60). By circumventing the 
long-held traditions, Luke's Jesus sets himself against those interpretations of the Bible that prove oppressive to the vulnerable. He opposes interpretations that tend to perpetuate domination veiled as religious piety. He attacks the colonial social edifices that had been legitimated by appeal to Torah, against Torah's own emancipatory thrust. In doing this, Jesus restored the honour of the marginalized and the down trodden, and removed the shame that stigmatized them. It is this radical and subversive interpretation that underlie Jesus' teachings in general and through parables, teachings that repudiated the domineering systems of colonialism, an exposé that inaugurates a domination-free order, a space of a new "empire" where God, and not Caesar reigns, thus an "empire of God ruled by a prince of peace that comes with love and justice" (Sugirtharajah 2016: 9). It is this sort of interpretation that Jesus requires of disciples.

\subsection{Conclusion}

Readings and understanding of scriptures are socially conditioned and as such dependent on worldviews and experiences of the reader, whether conscious or not, reads not from a vacuum but from a particular space and experience. This is the understanding that the colonial missionaries and successive western oriented scholarship (Blount, 1995) missed thereby advancing interpretations and a gospel that was not only foreign and abstract, but one that alienated colonial subjects from their socioeconomics and political endowments thereby setting them for self-impoverishment. Missionaries like Mackenzie who advocated for colonization and proclamations that treated texts as apolitical remains to date scandalous and requires resistance and overhaul in favour of a gospel whose substance is human transformation and emancipation. The trauma of colonial times still haunts Kenya's neo-colonial context which is rife with corruption and abject poverty for the majority of the populace. By adopting postcolonial optical viewpoint, former missionary founded churches in Kenya need to come to terms with the nature of political propaganda where a few political benefactors "swim" in unmerited wealth stolen from the poor but disguised as hard work. There is need to debunk the colonial missionaries' readings which are quite prevalent and offer the much-needed prophetic service aimed at emancipation and transformation. There is urgent need to incorporate social equity dimension as part of the gospel component. To embrace postcolonial "optics", provides a platform that accords space(s) to (neo)colonial subjects and all that are oppressed and muted to bring their voices to the landscape of biblical hermeneutics, resisting oppressive ideologies within and outside texts. Postcolonial hermeneutics therefore becomes a call for the Kenya church to action, to be part of a movement that constantly checks and re-checks the vitalities of their hermeneutics for the sake of preaching a gospel that upholds human dignity. It is a call to a counter movement underpinned by the conviction that any biblical interpretation devoid of the deeply charged interaction between the imperial presence and colonial subjects' refusal to be trampled upon, is nothing but a scandalous (mis)interpretation of Jesus' overall teachings and demands for freedom from the trappings of imperialism.

\section{References}

Anderson J.C. and Moore D. Stephen. Mark \& Method, New Approaches in Biblical Studies.

Fortress Press: Minneapolis, 1992.

Crossan Dominic J. The Historical Jesus: The Life of A Mediterranean Jewish Peasant. Harper San Francisco, 1992

Who Killed Jesus, Exposing the Roots of anti-Semitism in the Gospel Story of the Death of Jesus. Harper New York, 1995

Donaldson E. Laura \& Pui-lan Kwok. Postcolonialism, Feminism \& Religious Discourse. Routledge: New York, 2002.

Haynes R. Stephen and McKenzie L. Stephen. An Introduction to Biblical Criticisms and the Application: To Each its Own Meaning. Westminster John Knox Press, Louisville/London. Leiden, 1999, Revised and Expanded.

Herzog William. Parables as Subversive Speech; Jesus as Pedagogue of the Oppressed; Louisville, KY: Westminster/John Knox Press, 1994.

Herzog II William. "Jesus against domination" for the Historical Jesus Section at the Society of Biblical Literature annual meeting in Kansas City, Mo., 24, 1991.

Horsley, Richard A. Jesus and Empire: The Kingdom of God and the New World Disorder. Minneapolis: Fortress, 2002.

Johnson Timothy Luke. Sacra Pegina: The Gospel of Luke. The Liturgical Press, Collegeville Minnesota, 1991.

Kithinji Kiambi J. Postcolonial redaction of socio-economic parables in Luke's gospel and a Kenyan application, Lambert Academic: Berlin, 2008.

http://hdl.handle.net/10413/120

Krause Deborah. 1 Timothy: A New Biblical Commentary, T\&T Clark International, 2004

Kummel G. Werner; Introduction to the New Testament; Revised Edition. Abingdon Press: Nashville, 1975.

Musa Dube, Anderson M. Mbuvi and Dora Mbuwayesonga. "Post-Colonial Perspectives in African 
Biblical Interpretations", Society of Biblical Literature, Atlanta, 2012

Marshall Howard. New International Greek Testament Commentary: Commentary on Luke. William Eerdmans Publishing Company, Grand rapids: Michigan, 1978.

Nollard John. Word Biblical Commentary: Luke 9:21-18:34, Word Books, Publisher. Dallas, Texas. 1993.

Riley J. Gregory. One Jesus, Many Christs: How Jesus Inspired Not One True Christianity but Many. Fotress Press, Minneapolis, 1997.

Sugirtharajah R.S. (ed). Voices from the margin; Interpreting the Bible in the Third world. Marynoll: Orbis, 2016, third Edition.

Stephen D. Moore. Empire and apocalypse: Post colonization and the New Testament. Sheffield: Sheffield Phoenix, press, 2006.

Scott Bernard Brandon. Hear Then the Parable: A Commentary on the Parables of Jesus; Fortress Press, Minneapolis, 1989.

Pieter de Vries. "Methodology and Hermeneutics in a Challenging Socio-Political Context: The first twenty-five years of The New Testament Society of South Africa" (1965-1990)- JSNTSA, Part Two, Vol 39, No 2 (2005).

www.Jstor.org /stable/43048545.

Punt Jeremy. "The New Testament, Theology and Imperialism; Some Post-Colonial remarks on 'Beyond New Testament Theology”, Neotestamentica Vol. 35, No 1 (2001), 129-145, New Testament Society of Southern Africa, www.jstor.org /stable/43048420

. Postcolonial Biblical Interpretation; Reframing Paul, Brill/Boston, 2015

West Gerald, 2008. https://pdfs.semantic.scholar.org

Funk Robert. Honest to Jesus: Jesus for a New Millennium, Harper Collins, New york; 1996.

Luise Schottroff and Wolfgang Stegemann. Jesus and the Hope of the Poor. Trans by Mathew J O'Connell, Maryknoll, NY: Orbis Books, 1986.

R. P. Saller. Personal Patronage Under the Early Empire. Cambridge: Cambridge University Press, 1982.

Placher William C. Jesus the Savior, The Meaning of Jesus Christ for Christian Faith. Westminster John Knox Press Louisville, 2001.

Wink Walter. Engaging the Powers: Discernment and Resistance in a World of Domination. Fortress Press: Minneapolis, 1992. 